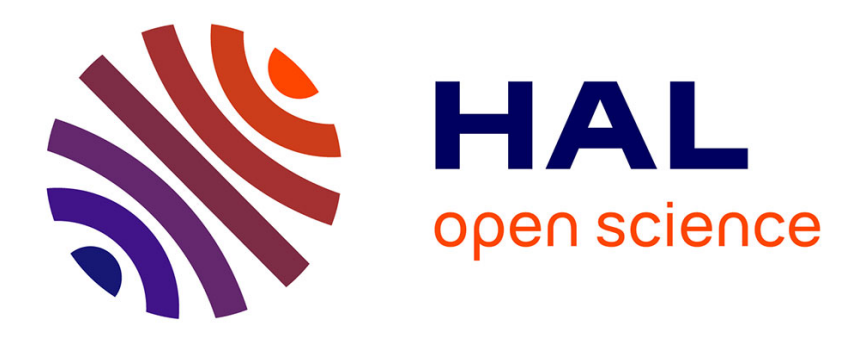

\title{
Effect of chestnut tannin on the fermentability of soyabean meal nitrogen in the rumen
}

\author{
Fabrice Mathieu, Jp Jouany
}

\section{To cite this version:}

Fabrice Mathieu, Jp Jouany. Effect of chestnut tannin on the fermentability of soyabean meal nitrogen in the rumen. Annales de zootechnie, 1993, 42 (2), pp.127-127. hal-00888877

\section{HAL Id: hal-00888877 \\ https://hal.science/hal-00888877}

Submitted on 1 Jan 1993

HAL is a multi-disciplinary open access archive for the deposit and dissemination of scientific research documents, whether they are published or not. The documents may come from teaching and research institutions in France or abroad, or from public or private research centers.
L'archive ouverte pluridisciplinaire HAL, est destinée au dépôt et à la diffusion de documents scientifiques de niveau recherche, publiés ou non, émanant des établissements d'enseignement et de recherche français ou étrangers, des laboratoires publics ou privés. 


\title{
Effect of chestnut tannin on the fermentability of soyabean meal nitrogen in the rumen
}

\author{
F Mathieu, JP Jouany \\ INRA, station de recherches sur la Nutrition des herbivores, unité de la Digestion microbienne, \\ centre de Clermont-Theix, 63122 Saint-Genès-Champanelle, France
}

Natural tannins combine with proteins to form very stable complexes, protecting them against bacterial deamination in the rumen (Zelter et al, 1970). In the present study, we used tannins extracted from chestnut wood shavings which were autoclaved at $110^{\circ} \mathrm{C}$ at a pressure of 2 bars. The solution of tannins ( $4 \%$ in dry matter) was then atomized.

Using an in vitro technique (Jouany and Thivend, 1986) the fermentability of soyabean meal (SM) nitrogen was calculated by comparing the production of $\mathrm{N}-\mathrm{NH}_{3}$ over a 6 -h period in the fermentors without SM with that of fermentors fed with SM. The end-products of microbial termentation were also measured: volatile fatty acids (VFA), gases, $\mathrm{N}-\mathrm{NH}_{3}$ uptake by bacteria. The dry extracts containing $77 \%$ tannins were added to fermentors in powder form just before inoculating them at different doses: $0.2,1.1$ and $5.3 \%$ of SM dry matter.

Doses of 0.2 and $1.1 \%$ SM dry matter significantly decreased the fermentability of the nitrogen in the meal, but had no effect on microbial metabolites (table I). The dose at $5.3 \%$ did not decrease nitrogen fermentability any more than this, but greatly reduced the production of microbial metabolites and the ammonia nitrogen uptake by the bacteria.

In conclusion, we can assume from these results that the addition of such tannins to a diet will reduce the fermentability of protein nitrogen in the rumen. Consequently, the flow of dietary amino acids into the duodenum of ruminants could be increased, as well as the total duodenal amino acid flow if $\mathrm{N}^{-\mathrm{NH}_{3}}$ requirements for microbes are met by supplementation of urea or ammonia salts.

Jouany JP, Thivend P (1986) Anim Feed Sci Technol 15, 215-229

Zelter SZ, Leroy F, Tissier JP (1970) Ann Biol

Anim Biochim Biophys 10, 401-412

Table I. Effect of tannins on nitrogen fermentability and on the major end products of rumen fermentations $(n=8)$.

\begin{tabular}{|c|c|c|c|c|c|}
\hline \multirow[t]{2}{*}{ Parameters } & \multicolumn{2}{|c|}{ Tannin extracts } & \multicolumn{2}{|c|}{ (\% DM soyabean meal) } & \multirow[t]{2}{*}{$S D M^{\prime}$} \\
\hline & 0 & 0.2 & 1.1 & 5.3 & \\
\hline $\begin{array}{l}\text { Fermentability of soyabean meal nitrogen * } \\
\text { Production of total VFA } \\
\text { Production of gases *** } \\
\mathrm{N}-\mathrm{NH}_{3}{ }^{2} \text { uptake by bacteria (mg/ferm/ } 6 \mathrm{hr} \text { ) }\end{array}$ & $\begin{array}{r}36.8^{\mathrm{a}} \\
69.9^{\mathrm{a}} \\
2405^{\mathrm{a}} \\
168.9^{\mathrm{a}}\end{array}$ & $\begin{array}{r}14.7^{b} \\
67.0^{\mathrm{a}} \\
2360^{\mathrm{a}} \\
157.5^{\mathrm{a}}\end{array}$ & $\begin{array}{r}5.7^{\mathrm{c}} \\
64.7^{\mathrm{a}} \\
2201^{\mathrm{a}} \\
147.7^{\mathrm{a}}\end{array}$ & $\begin{array}{r}6.8^{c} \\
37.4^{b} \\
2033^{b} \\
94.0^{b}\end{array}$ & $\begin{array}{r}5.3 \\
3.4 \\
156 \\
11.1\end{array}$ \\
\hline
\end{tabular}

Means with different superscripts on the same line are significantly different $(P<0.05) ;{ }^{1}$ standard deviation of means; ${ }^{2}$ ammonia nitrogen; * $\%$ of $\mathrm{N}$ fermented for $6 \mathrm{hr} ;{ }^{* *}$ mMol/fermentor $/ 6 \mathrm{hr} ;$ "** ml/fermentor/6 hr. 